\title{
Cloning and sequencing of protein L-isoaspartyl O-methyl transferase of Salmonella Typhimurium isolated from poultry
}

\author{
S. K. Dixit ${ }^{1}$, D. P. Hota ${ }^{2}$, M. Kumawat ${ }^{2}$, T. K. Goswami ${ }^{1}$ and M. Mahawar²
}

1. Immunology Section, Indian Veterinary Research Institute, Izatnagar, Bareilly, Uttar Pradesh, India; 2. Division of Biochemistry, Indian Veterinary Research Institute, Izatnagar, Bareilly, Uttar Pradesh, India.

Corresponding author: S. K. Dixit, e-mail: sunildixit1987@gmail.com, DPH: durgaprasad.hota04@gmail.com, MK:0711mworld@gmail.com, TKG: goswami.tapas@gmail.com, MM: manishbiochemistry@gmail.com Received: 16-05-2014, Revised: 28-07-2014, Accepted: 04-08-2014, Published online: 25-09-2014

doi: 10.14202/vetworld.2014.712-716. How to cite this article: Dixit SK, Hota DP, Kumawat M, Goswami TK, Mahawar M (2014) Cloning and sequencing of protein L-isoaspartyl O-methyl transferase of Salmonella Typhimurium isolated from poultry, Veterinary World 7(9): 712-716.

\begin{abstract}
Aim: To clone the Salmonella Typhimurium protein $L$-isoaspartyl $O$-methyl transferase (PIMT) enzyme and to analyze the sequence with PIMT gene of other pathogenic serovars of Salmonella.

Materials and Methods: Salmonella Typhimurium strain E-2375 was procured from the National Salmonella Center, IVRI. The genomic DNA was isolated from Salmonella Typhimurium. Polymerase chain reaction (PCR) was carried out to amplify PIMT gene using the designed primers. The PCR product was cloned into pET28c plasmid vector and transformed into Escherichia coli DH5 $\alpha$ cells. The plasmid was isolated from E. coli and was sequenced. The sequence was analyzed and submitted in Genbank.
\end{abstract}

Results: The PCR product revealed a distinct amplicon of 627 bp. The clone was confirmed by PCR. Sequencing data revealed 100\% homology between PIMT sequences from Salmonella Typhimurium strain E-2375 (used in the current study) and PIMT sequences of standard reported strain (Salmonella Typhimurium str. LT2) in NCBI data base. This submitted sequence in Genbank having accession no. KJ575536.

Conclusions: PIMT gene of Salmonella is highly conserved in most of the pathogenic Salmonella serovars. The PIMT clone can be used to isolate PIMT protein. This PIMT protein will be helpful to identify isoaspartate containing proteins thus can help in study Salmonella virulence.

Keywords: cloning, sequencing, Salmonella Typhimurium protein $L$-isoaspartyl $O$-methyl transferase, virulence.

\section{Introduction}

Salmonella enterica serovar Typhimurium (shortly Salmonella Typhimurium) is a Gram-negative, flagellated and facultative intracellular anaerobe grouped under the family enterobactericeae is widely known for its highly zoonotic importance [1]. This pathogenic bacterium infects wide range of animal host causing severe morbidity and mortality in animals and human [2,3]. Poultry birds mainly act as an asymptomatic reservoir host and its contaminated meat and eggs are the source of infection causing severe gastroenteritis in human and typhoid like disease in rodents [4]. Growing resistance to antibiotics [5], endemicity of infection and their career state encourages understanding the several aspects of its physiology and metabolism for novel vaccine development and its effective control. There are several virulence factor associated with the severity of infection [6]. The virulence associated enzyme mediated protein repairing modification mechanism associated with Salmonella for the confrontation of a hostile environment inside the host immune system. The phagocytic cells damage various macromolecules such as DNA,

Copyright: The authors. This article is an open access article licensed under the terms of the Creative Commons Attributin License (http:// creative commons.org/licenses/by/2.0) which permits unrestricted use, distribution and reproduction in any medium, provided the work is properly cited.
RNA and proteins by producing a battery of antimicrobials such as reactive oxygen species and reactive nitrogen species [7]. The proteins are the major target for this oxidative damage due to their abundance and oxidation leads to covalent modification of the amino acid residues and conformational changes in protein structure [8]. This protein modification brought about by various protein repairing enzymes may be present in Salmonella Typhimurium rescue from the oxidative damage and assist for intraphagosomal survival and its replication.

Out of the several protein repairing enzymes reported, protein $L$-isoaspartyl $O$-methyl transferase (PIMT) have been found to be effective for all the domains of the life, and this enzymes extensively studied in Escherichia coli [9] and Pyrococcus [10] and Vibrio cholera [11]. The way PIMT works are by repairing the damaged proteins like $L$-isoaspartyl residues to normal $L$-aspartyl in proteins by methyl transferase activities [12]. The housekeeping role of this enzyme catalyzes the methyl esterification by transfer of methyl group from the $S$-adenosylmethionine to the $\alpha$-carboxyl group of $L$-isoaspartyl and $\beta$-carboxyl group of $D$-aspartyl residues via succinimide intermediate formation, which is hydrolyzed to a mixture of $L$-aspartyl and $L$-isoaspartyl residues in the ratio of $1: 3$ and subsequently restore their biological functions [13]. 
As per our knowledge, no work has been reported until date regarding the importance of PIMT in Salmonella Typhimurium. Keeping this in view, the present study was carried out to clone and sequence the PIMT gene of $S$. Typhimurium and to analyze the sequence relationship with other pathogenic Salmonella.

\section{Materials and Methods}

The poultry isolate of Salmonella Typhimurium strain E-2375 was procured from National Salmonella Centre (Veterinary), Division of Bacteriology and Mycology, Indian Veterinary Research Institute, Izatnagar, India. The cultures were revived by growing in $\mathrm{LB}$ broth at $37^{\circ} \mathrm{C}$ overnight, and the isolated colonies were obtained by streaking on Hektoen Enteric Agar (HEA) plate. The cultures were confirmed by testing the purity, morphology and biochemical characteristics as per standard protocol [14]. Serotype confirmation was done by slide agglutination test using polyvalent antisera and tube agglutination test using somatic and flagellar group specific and factor antisera.

The genomic DNA was isolated as per the standard protocol (purelink ${ }^{\mathrm{TM}}$ genomic DNA isolation kit, Cat. no. K-1820-01, Invitrogen ${ }^{\mathrm{TM}}$, USA). To check the integrity of the DNA, about $0.5 \mu \mathrm{g}$ sample was run on $1 \% \mathrm{w} / \mathrm{v}$ agarose gel (Ultrapure ${ }^{\mathrm{TM}}$ agarose, Invitrogen, USA) prepared in $1 \mathrm{X}$ TAE [15]. The PIMT of Salmonella Typhimurium was amplified by using designed oligonucleotides primers (Table-1). The restriction enzymes NheI and BamHI sites were incorporated on 5' of forward and reverse primers, respectively.

PCR reaction was carried out using following constituents, $7.5 \mu \mathrm{l}$ of $2 \mathrm{mM}$ dNTPs mix, $1.5 \mu \mathrm{l}$ of PIMT FP and PIMT RP (10 pM/ $\mu$ l each), $1 \mu \mathrm{l}$ of $50 \mathrm{mM} \mathrm{MgCl}, 5 \mu \mathrm{l} \times 10$ PCR reaction buffer, $5 \mu \mathrm{l}$ Enhancer, $2 \mu \mathrm{l}(96 \mathrm{ng} / \mu \mathrm{l})$ of Salmonella Typhimurium genomic DNA as template and $0.5 \mu \mathrm{l}(2.5 \mathrm{U} / \mu \mathrm{l})$ of $P f x$ polymerase and the final reaction volume made up to $50 \mu \mathrm{l}$ with Nuclease free water. The PCR program was standardized with one cycle of the initial denaturation at $95^{\circ} \mathrm{C}$ for $5 \mathrm{~min}$, followed by 30 cycles each of denaturation $\left(95^{\circ} \mathrm{C}\right.$ for $\left.30 \mathrm{~s}\right)$, annealing $\left(60^{\circ} \mathrm{C}\right.$ for $\left.30 \mathrm{~s}\right)$ and extension $\left(72^{\circ} \mathrm{C}\right.$ for $\left.45 \mathrm{~s}\right)$ and final extension $\left(72^{\circ} \mathrm{C}\right.$ for $10 \mathrm{~min}$ ). The PCR products were checked by submarine gel electrophoresis on $1 \%$ agarose gel.

The amplified PCR product digested with NheI (5 $\mathrm{h}$ at $\left.37^{\circ} \mathrm{C}\right)$ and then, BamHI was added to

Table-1: Designed primers of PIMT of S. enterica subsp. enterica serovar Typhimurium.

\begin{tabular}{ll}
\hline Forward primer, & 5'-ATATAT GCTAGC ATG GTA \\
PIMT F (Nhel) & AGT GGA CGT GTA CAG-3' \\
Reverse primer, & 5'-ATATAT GGATCC GGC CAG \\
PIMT R (BamHI) & CTC TCC CTT GAC-3' \\
\hline
\end{tabular}

PIMT: Protein L-isoaspartyl O-methyl transferase,

S. enterica $=$ Salmonella enterica the reaction, and the mix was incubated for an additional $1 \mathrm{~h}$. Finally, heat inactivation was carried out at $80^{\circ} \mathrm{C}$ for $10 \mathrm{~min}$. The RE digested PIMT PCR product was gel purified using QIA quick gel extraction kit (Qiagen $^{\mathrm{TM}}$, Germany) using manufacturers protocol. The pET28c vector was digested in a similar manner with NheI and BamHI restriction enzymes to generate complementary overhangs. Following RE digestion the vector was dephosphorylated at $37^{\circ} \mathrm{C}$ for $30 \mathrm{~min}$ using shrimp alkaline phosphatase. The enzymes were heat inactivated at $80^{\circ} \mathrm{C}$ for $10 \mathrm{~min}$. The digested and dephosphorylated pET28c was gel purified. NheIBamHI digested, gel purified PIMT gene was ligated into the digested pET28c expression vector. A 3:1 molar ratio of insert (PIMT) to vector (pET28c) was used. The resultant recombinant plasmid (pET28cPIMT Plasmid) was initially transformed into chemically competent $E$. coli DH5 $\alpha$ cells with $5 \mu \mathrm{l}$ of ligated reaction mix as per standard protocol. Screening of recombinant clones was done by colony PCR and RE digestion. The PIMT gene cloned in pET28c plasmid was confirmed by sequencing by using plasmid as template and $\mathrm{T} 7$ terminator and promoter as sequencing primers. Further, the recombinant clone was confirmed by SDS-PAGE after addition of isopropyl $\beta$ - $D$-thiogalactopyranoside in the bacterial culture at the final concentration of $0.5 \mathrm{mM}$ for $3 \mathrm{~h}$ at $25^{\circ} \mathrm{C}$. The sequencing results were assembled and analyzed using DNASTAR package analysis software. The final sequence was aligned with the available PIMT gene of S. enterica serovar Typhimurium str. LT2. The sequence was submitted to NCBI Genbank. Further, the nucleotide sequence was subjected to nucleotide BLAST to compare for sequence similarities with other sequences available in the NCBI database (http://blast.ncbi.nl.nih.gov).

\section{Results}

Salmonella Typhimurium strain of poultry origin was used in the current study. The strain showed typical morphological, cultural and serological characteristics of the Salmonella. On HEA plate, the isolate produced smooth, transparent, black centered colonies with greenish periphery (Figure-1). In slide agglutination test, the organism reacted with the standard positive serum.

The genomic DNA from Salmonella was isolated, and the ratio of $\mathrm{OD}_{260 / 280}$ was 1.97, which indicates the DNA was pure. The PCR amplified PIMT was purified and the concentration of the PCR product was $\sim 20 \mathrm{ng} / \mu \mathrm{l}$. This PIMT insert was directionally cloned into an expression vector pET28c and was PCR amplified using PIMT-pET28c as template. This DNA migrated as a single band of approximately $627 \mathrm{bp}$ in $1 \%$ agarose gel (Figure-2 and lane 1 and 2) as that of amplified insert DNA (Data not shown). The nucleotide sequence was confirmed by restriction digestion and sequencing and was submitted to NCBI GenBank (accession no. KJ575536). Sequencing data were 
analyzed using DNA star software and NCBI home page and $100 \%$ homology between PIMT sequences from Salmonella Typhimurium strain E-2375 (used in the current study) and retrieved $S$. Typhimurium LT2 PIMT (Figure-3). After SDS-PAGE following induction a band migrating $\sim 28 \mathrm{kDa}$ was observed in induced lane that was absent in the corresponding uninduced control lane (Figure-4).

The sequence when subjected to nucleotide BLAST search revealed a high degree of similarity with other Salmonella serovar (Table-2). The PIMT gene is highly conserved in most of the pathogenic serovars of Salmonella as evidenced from the sequence analysis. The obtained sequences shown $100 \%$ similarity with PIMT gene sequences of Salmonella Typhimurium

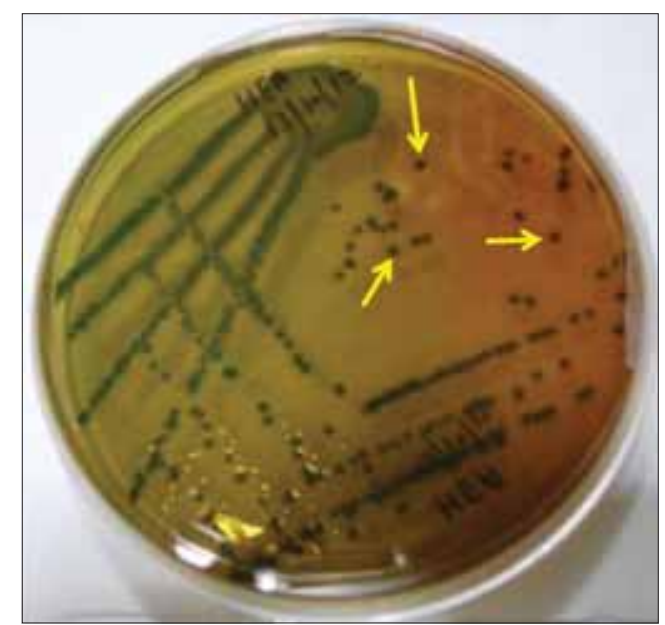

Figure-1: Growth of Salmonella Typhimurium E-2375 strain on Hektoen Enteric Agar plate. The cells were streaked and incubated at $37^{\circ} \mathrm{C}$ for overnight. I solated colonies are depicted by arrows.
DT104 (HF937208), Salmonella Typhimurium str. 08-1736 (CP006602), Salmonella Typhimurium str. D23580 (FN424405) and Salmonella Typhimurium SL1344 (FQ312003) and 99\% similarity with str. DT2 (HG326213), S. Newport str. SL254 (CP001113), Salmonella Bareilly str. CFSAN000189 (CP006053), Salmonella Enteritidis str. EC20100325 (CP007360), Salmonella Anatum str. ATCC BAA1592 (CP007531), Salmonella Heidelberg str. SL476 (CP001120) and S. Enteritidis str. EC20100130 (CP007358). The expressed protein was isolated from

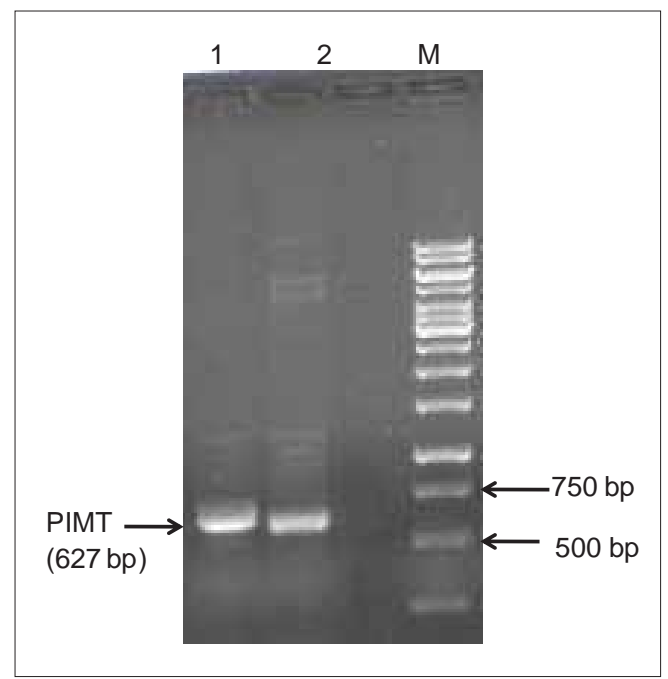

Figure-2: Polymerase chain reaction (PCR) amplification of Salmonella Typhimurium protein L-isoaspartyl O-methyl transferase using plasmid DNA template. The amplified products were analysed on $1 \%$ agarose gel. Lane $\mathrm{M}: 1 \mathrm{~kb}$ DNA ladder, Lane 1 and 2: PCR amplified products marked by arrow.

Table-2: Results of nucleotide blast showing similarity of PIMT gene of S. enterica serovar Typhimurium strain E-2375 with other Salmonella serovars.

\begin{tabular}{|c|c|c|c|c|c|}
\hline $\begin{array}{l}\text { Accession } \\
\text { number }\end{array}$ & Description & $\begin{array}{l}\text { Maximum } \\
\text { score }\end{array}$ & $\begin{array}{l}\text { Total } \\
\text { score }\end{array}$ & $\begin{array}{l}\text { Query } \\
\text { coverage \% }\end{array}$ & $\begin{array}{l}\text { Maximum } \\
\text { indent } \%\end{array}$ \\
\hline HF937208 & $\begin{array}{l}\text { S. enterica subsp. enterica serovar Typhimurium } \\
\text { DT104 main chromosome, complete genome }\end{array}$ & 1153 & 1153 & 100 & 100 \\
\hline СР006602 & $\begin{array}{l}\text { S. enterica subsp. enterica serovar Typhimurium } \\
\text { str. 08-1736, complete genome }\end{array}$ & 1153 & 1153 & 100 & 100 \\
\hline FN424405 & $\begin{array}{l}\text { S. enterica subsp. enterica serovar Typhimurium } \\
\text { str. D23580 complete genome }\end{array}$ & 1153 & 1153 & 100 & 100 \\
\hline FQ312003 & $\begin{array}{l}\text { S. enterica subsp. enterica serovar Typhimurium } \\
\text { SL1344 complete genome }\end{array}$ & 1153 & 1153 & 100 & 100 \\
\hline HG326213 & $\begin{array}{l}\text { S. enterica subsp. enterica serovar Typhimurium } \\
\text { str. DT2, complete genome }\end{array}$ & 1147 & 1147 & 100 & 99 \\
\hline СР001113 & $\begin{array}{l}\text { S. enterica subsp. enterica serovar Newport str. } \\
\text { SL254, complete genome }\end{array}$ & 1136 & 1136 & 100 & 99 \\
\hline СР006053 & $\begin{array}{l}\text { S. enterica subsp. enterica serovar Bareilly str. } \\
\text { CFSAN000189, complete genome }\end{array}$ & 1120 & 1120 & 100 & 99 \\
\hline СР007360 & $\begin{array}{l}\text { S. enterica subsp. enterica serovar Enteritidis str. } \\
\text { EC20100325 genome }\end{array}$ & 1109 & 1109 & 100 & 99 \\
\hline СР007531 & $\begin{array}{l}\text { S. enterica subsp. enterica serovar Anatum str. } \\
\text { ATCC BAA-1592, complete genome }\end{array}$ & 1131 & 1131 & 100 & 99 \\
\hline CР001120 & $\begin{array}{l}\text { S. enterica subsp. enterica serovar Heidelberg str. } \\
\text { SL476, complete genome }\end{array}$ & 1125 & 1125 & 100 & 99 \\
\hline СР007358 & $\begin{array}{l}\text { S. enterica subsp. enterica serovar Enteritidis str. } \\
\text { EC20100130, complete genome }\end{array}$ & 1109 & 1109 & 100 & 99 \\
\hline
\end{tabular}

PIMT: Protein L-isoaspartyl O-methyl transferase, S. enterica=Salmonella enterica 
Available at www.veterinaryworld.org/Vol.7/September-2014/17.pdf

\begin{tabular}{|c|c|c|c|c|c|c|c|}
\hline \multicolumn{2}{|c|}{$\begin{array}{l}\text { Score } \\
1153 \text { bits }(624)\end{array}$} & $\begin{array}{l}\text { Expect } \\
0.0\end{array}$ & \multicolumn{2}{|c|}{$\begin{array}{l}\text { Identities } \\
624 / 624(100 \%)\end{array}$} & $\begin{array}{l}\text { Gaps } \\
0 / 624(0 \%)\end{array}$ & \multicolumn{2}{|c|}{$\begin{array}{l}\text { Strand } \\
\text { Plus/Plus }\end{array}$} \\
\hline Query & 122 & \multirow{2}{*}{\multicolumn{5}{|c|}{$\begin{array}{l}\text { ATGGTAAGTGGACGIGIACAGGCTCTICTIGAACAATIGCGCGCGCAGGGCATCAGAGAT } \\
111111111111111111111111111111111111111111111 \\
\text { ATGGTAAGGGACGIGIACAGGCICTICTIGAACARTGCGCGCGCAGGGCATCAGAGA }\end{array}$}} & 181 \\
\hline Sbjet & 1 & & & & & & 60 \\
\hline Query & 182 & \multirow{2}{*}{\multicolumn{5}{|c|}{ 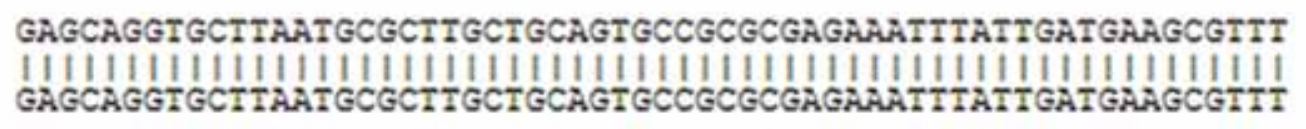 }} & 241 \\
\hline Sbjec & 61 & & & & & & 120 \\
\hline Query & 242 & \multirow{2}{*}{\multicolumn{5}{|c|}{ 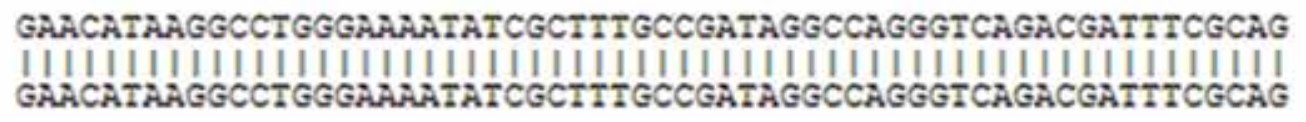 }} & 301 \\
\hline Sbjct & 121 & & & & & & 180 \\
\hline Query & 302 & \multirow{2}{*}{\multicolumn{5}{|c|}{ 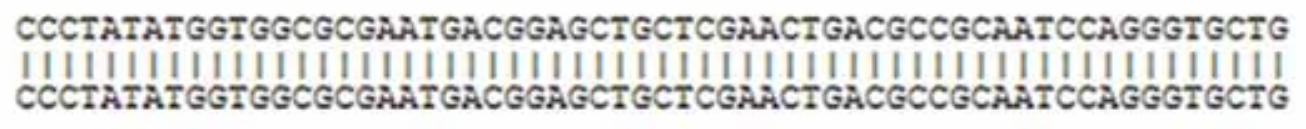 }} & 361 \\
\hline Sbjet & 181 & & & & & & 240 \\
\hline Query & 362 & \multirow{2}{*}{\multicolumn{5}{|c|}{ 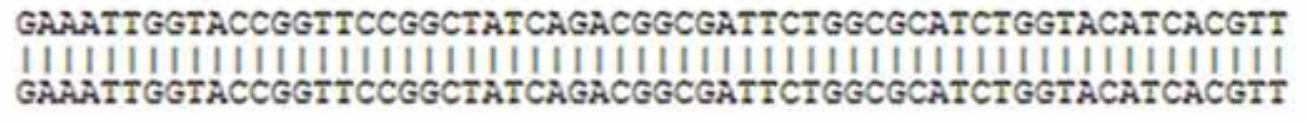 }} & 42 \\
\hline Sbjet & 241 & & & & & & 300 \\
\hline Query & 422 & \multirow{2}{*}{\multicolumn{5}{|c|}{ 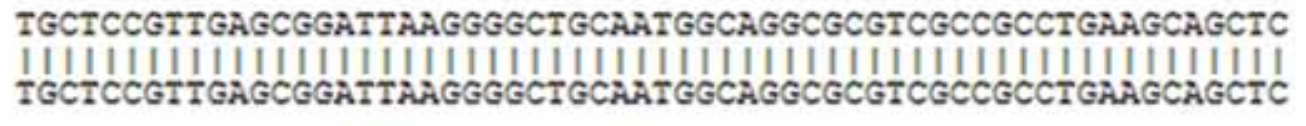 }} & 481 \\
\hline Sbjet & 301 & & & & & & 360 \\
\hline Query & 482 & \multirow{2}{*}{\multicolumn{5}{|c|}{$\begin{array}{l}\text { GATTIACATAATGTTTCTACCCGTCATGGCGATGGCTGGCAAGGCTGGCAGGCGCGTGCG } \\
\text { I1111111111111111111111111111111111111111111111111 } \\
\text { GATTACATARGITCIACCCGICATGGCGATGGTGGCAAGGCTGGCAGGCGCGIGCG }\end{array}$}} & 54 \\
\hline Sbjet & 361 & & & & & & 420 \\
\hline Query & 542 & \multirow{2}{*}{\multicolumn{5}{|c|}{ 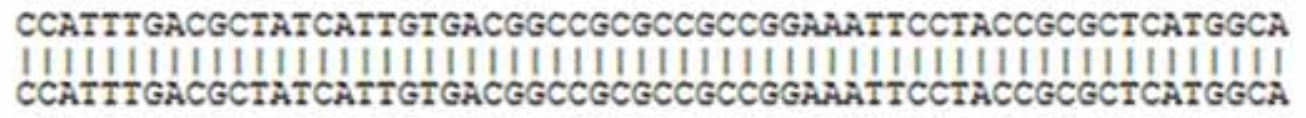 }} & 601 \\
\hline Sbjet & 421 & & & & & & 480 \\
\hline Query & 602 & \multirow{2}{*}{\multicolumn{5}{|c|}{ 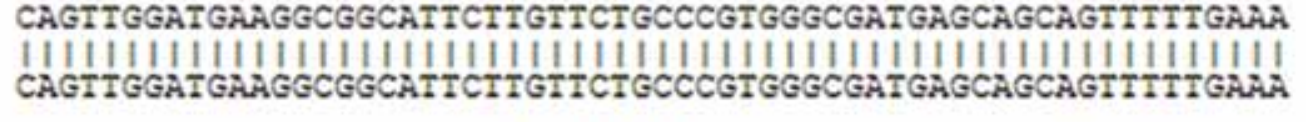 }} & $6 e$ \\
\hline Sbjet & 481 & & & & & & 540 \\
\hline Query & 662 & \multirow{2}{*}{\multicolumn{5}{|c|}{ 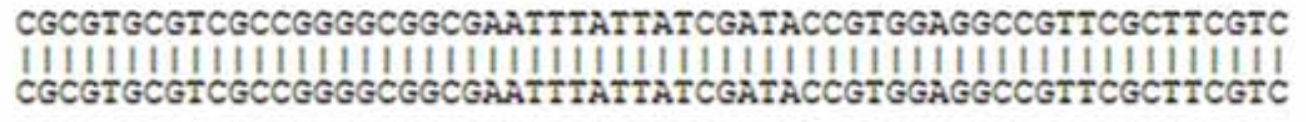 }} & 721 \\
\hline Sbjet & 541 & & & & & & 600 \\
\hline Query & 722 & \multirow{2}{*}{\multicolumn{2}{|c|}{ 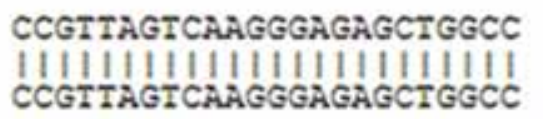 }} & 745 & & & \\
\hline Sbjec & 601 & & & 624 & & & \\
\hline
\end{tabular}

Figure-3: Sequence analysis of protein L-isoaspartyl O-methyl transferase (PIMT) from positive clones resembling $100 \%$ homology: Query-PIMT sequence obtained by sequencing, subject-retrieved PIMT sequence of S. Typhimurium LT2 strain from NCBI.

the soluble fraction and migrated as around $28 \mathrm{kDa}$ band on SDS gelas histidine was fused with PIMT.

\section{Discussion}

The importance of PIMT has been demonstrated in E. coli. The E. coli $\triangle$ pimt (mutant PIMT) showed compromised survival in stationary phase of growth when subjected to oxidative stress [9]. This protein repairing enzyme is highly conserved across the phylogenetic domain including eubacteria, archaebacteria, protozoa, fungi, nematodes, mammals and plants [16]. The structural sequence similarities reveal the same functional characterization of almost all Salmonella serovars. To know more about PIMT role and establishment of the importance of this enzyme, cloning and sequencing is primary attempt that can be further helpful to produce the PIMT protein for its functional characterization by identifying its target to establish its virulence properties.

\section{Conclusion}

Salmonellosis caused by Salmonella Typhimurium is an important food borne intracellular pathogen and disease spreads mainly due to consumption of contaminated poultry products. Intra phagocytic survival of Salmonella Typhimurium depends upon its ability to quench phagocyte generated oxidants and repair of macromolecules. Although this bacterium harbors several primary antioxidant enzymes, its survival inside the macrophages at least in part depends upon repair of damaged proteins. The repair of the isoaspartyl proteins under oxidative stress is crucial to reactivate their 


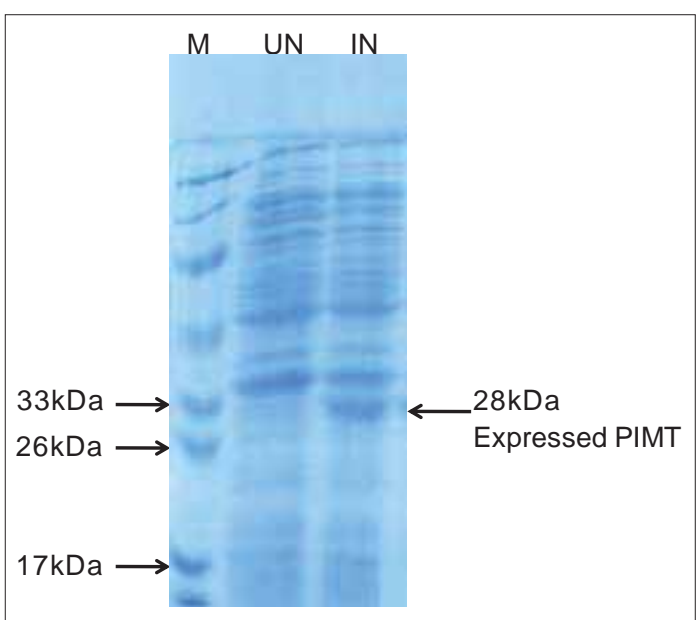

Figure-4: SDS-PAGE analysis of Escherichia coli bacterial cel lysate following induction of IPTG. Lane UN and IN are uninduced and induce cultures. Lane: $M$ is the protein marker.

functions. This PIMT enzyme is responsible for the repair of the same to rescue its functions. This PIMT enzyme of Salmonella is highly conserved in the nucleotide sequence among the pathogenic Salmonella serovars. The similarity in the sequences of the cloned product with other Salmonella serovars suggests its importance in the utility of PIMT enzyme for its restorement of protein function as a mean of intraphagosomal survival. It is not yet cleared whether PIMT can be used as detective antisera for confirmation of clinical cases of Salmonella, which needs further experimental study.

\section{Authors' Contributions}

SKD, TKG and MM designed the experiments. SKD and DPH carried out the experimental work. MM, TKG and SKD were involved in scientific discussion and analysis of the data. SKD and MK drafted and revised the manuscript. All authors read and approved the final manuscript.

\section{Acknow ledgments}

Authors are thankful to the Director, IVRI and National Fund for Basic, Strategic and Frontier Application Research in Agriculture (NFBSFARA), the Indian Council of Agricultural Research (ICAR), New Delhi for providing the necessary funds (in part) and facilities for the current study. Authors are also thankful to the Head, Bacteriology and Mycology, IVRI, Izatnagar for providing Salmonella Strain.

\section{Competing I nterests} interests.

The authors declare that they have no competing

\section{References}

1. Christou, L. (2011) The global burden of bacterial and viral zoonotic infections. Clin. Microbiol. Infect., 17(3): 326-330.

2. Kingsley, R.A., Msefula, C.L., Thomson, N.R., Kariuki, S. and Holt, K.E. (2009) Epidemic multiple drug resistant Salmonella Typhimurium causing invasive disease in sub-Saharan Africa have a distinct genotype. Genome Res. 19(12): 2279-2287.

3. Velge, P., Cloeckaert, A. and Barrow, P. (2005). Emergence of Salmonella epidemics: The problems related to Salmonella enterica serotype enteritidis and multiple antibiotic resistance in other major serotypes. Vet. Res., 36(3): 267-288.

4. Wales, A.D. and Davies, R.H. (2011) A critical review of Salmonella Typhimurium infection in laying hens. Avian. Pathol., 40(5): 429-436.

5. Parry, C.M. and Threlfall, E.J. (2008) Antimicrobial resistance in typhoidal and nontyphoidal salmonellae. Curr. Opin. Infect. Dis., 21(5): 531-538.

6. Ibarra, J.A. and Steele-Mortimer, O. (2009) Salmonella- the ultimate insider. Salmonella virulence factors that modulate intracellular survival. Cell. Microbiol., 11(11): 1579-1586.

7. Haraga, A., Ohlson, M.B. and Miller, S.I., (2008) Salmonella interplay with host cells. Nat. Rev. Microbiol., 6(1): 53-66.

8. Mahawar, M., Tran, V., Sharp, J.S. and Maier, R.J. (2011) Synergistic roles of Helicobacter pylori methionine sulfoxide reductase and GroEL in repairing oxidant-damaged catalase. J. Biol. Chem., 286(21): 19159-19169.

9. Li, C. and Clarke, S. (1992) Protein methyltransferase specific for altered aspartyl residues is important in Escherichia coli stationary-phase survival and heat-shock resistance. Proc. Natl. Acad. Sci., 89(20): 9885-9889.

10. Lowenson, J.D. and Clarke, S., (1992) Recognition of D-aspartyl residues in polypeptides by the erythrocyte L-isoaspartyl/D-aspartyl protein methyltransferase. Implication for the repair hypothesis. J. Biol. Chem., 267(9): 5985-5995.

11. Chatterjee, T., Pal, A., Chakravarty, D., Dey, S., Saha, R.P. and Chakrabarti, P. (2013) Protein $L$-isoaspartylO-methyltransferase of Vibrio cholerae: Interaction with cofactors and effect of osmolytes on unfolding. Biochimie., 95(4): 912-921.

12. Verma, P., Singh, A., Kaur, H. and Majee, M. (2010) Protein $L$-isoaspartyl methyltransferase 1 (CaPIMT1) from chickpea mitigates oxidative stress-induced growth inhibition of E. coli. Planta., 231(2): 329-336.

13. Fang, P., Li, X., Wang, J., Xing, L., Gao, Y., Niu, L. and Teng, M. (2010) Crystal structure of the protein $L$-isoaspartyl methyltransferase from Escherichia coli. Cell, Biochem. Biophys., 58: 163-167.

14. Agarwal, R.K., Bhilegaonkar, K.N., Singh, D.K., Ashok, K. and Rathore, R.S. (2003) Laboratory manual for the isolation and identification of foodborne pathogens. Indian Veterinary Research Institute, Izatnagar, Bareilly, India. p100.

15. Sambrook, J. and Russel, D.W. (2001) In: Molecular Cloning, a Laboratory Manual. $3^{\text {rd }}$ ed. Vol. I. CSHL Press, USA. p8.2-8.7.

16. O’Connor, C.M. (2006) Protein $L$-isoaspartyl/D-aspartyl $O$-methyltransferases: Catalysts for protein repair. In protein methyltransferases. Enzymes., 24: 383-431. 